\title{
SISTEM MANAJEMEN RISIKO KONTAMINASI PADA RANTAI PASOK PANGAN (STUDI KASUS : SUSU PASTEURISASI)
}

\section{RISK MANAGEMENT SYSTEM FOR CONTAMINATION ON FOOD SUPPLY CHAIN (CASE STUDY : PASTEURIZED MILK)}

\author{
Nindya Malvins Trimadya ${ }^{1)^{*}}$, Hartrisari Hardjomidjojo ${ }^{2)}$ dan Elisa Anggraeni' ${ }^{2)}$ \\ ${ }^{1)}$ Pusat Perumusan Standar, Badan Standardisasi Nasional. Gedung I BPPT \\ Jl. M.H. Thamrin No.8 Kebon Sirih, Jakarta Pusat 10340, Indonesia \\ Email : malvins82@gmail.com \\ ${ }^{2}$ Departemen Teknologi Industri Pertanian, Fakultas Teknologi Pertanian, IPB \\ Kampus IPB Dramaga, Bogor 16680, Indonesia
}

Makalah: Diterima 16 November 2017; Diperbaiki 9 Mei 2018; Disetujui 20 Mei 2018

\begin{abstract}
Intentional contamination threats to food supply chain has increased. Risk management can be used to handle such threats. Risk management methods such as International Organization for Standardization (ISO) 22000, Hazard Analysis and Critical Control Points (HACCP) can only be applied for unintentional contamination threats. The objectives of this research was to develop a model of risk management for intentional contamination threat on pasteurized milk supply chain in Indonesia. A case study using Threat Assessment Critical Control Point (TACCP) was conducted in PT XYZ to apply the model. The results showed that the threats can be divided into food fraud risk and food defense risk. The threat to this pasteurized product from this company could be classified as low risk by applying actions, such as prevention, detection, and deterrence.
\end{abstract}

Keywords : food defense, food fraud, intentional contamination, pasteurized milk

\section{ABSTRAK}

Ancaman terjadinya kontaminasi yang disengaja pada rantai pasok pangan cenderung meningkat. Manajemen risiko dapat digunakan untuk menangani ancaman tersebut. Metode manajemen risiko seperti ISO 22000, Hazard Analysis and Critical Control Points (HACCP) hanya dapat diterapkan untuk menangani ancaman kontaminasi tidak disengaja. Tujuan penelitian ini adalah membuat model manajemen risiko kontaminasi yang disengaja pada rantai pasok susu pasteurisasi di Indonesia. Studi kasus menggunakan Threat Assessment Critical Control Point (TACCP) dilakukan di PT. XYZ untuk mengaplikasikan model. Hasil menunjukkan bahwa ancaman kontaminasi yang disengaja terdiri dari risiko food fraud dan risiko food defense. Ancaman pada produk susu pasteurisasi pada perusahaan ini dapat dikategorikan low risk dengan menerapkan tindakan preventif, deteksi, dan menghalangi.

Keywords: food defense, food fraud, kontaminasi disengaja, susu pasteurisasi

\section{PENDAHULUAN}

Kejadian keracunan akibat konsumsi pangan di Indonesia masih cukup tinggi. Data dari Badan Pengawas Obat dan Makanan (BPOM) pada tahun 2016 menunjukkan bahwa terdapat Kejadian Luar Biasa (KLB) keracunan pangan sebanyak 60 kejadian dengan jumlah orang terpapar sebanyak 3.351 orang sakit dan 7 orang meninggal dunia (BPOM, 2016). Keracunan pangan umumnya terjadi karena adanya kontaminasi oleh kontaminan yang secara tidak sengaja.

Pada perkembangannya, ancaman kontaminasi pada pangan dapat terjadi karena tindakan yang disengaja. Spink dan Moyer (2011) menjelaskan bahwa risiko pada pangan akibat tindakan yang disengaja adalah risiko food fraud dan risiko food defense. Food fraud terdiri dari beberapa subtipe, salah satunya adalah economically motivated adulteration (EMA) yaitu adanya penambahan adulterant dengan bertujuan meningkatkan nilai suatu produk pangan sehingga mendapatkan keuntungan ekonomi. Kejadian terkait food fraud di Indonesia antara lain daging gelonggongan, madu palsu, biskuit dan cokelat yang mengandung ganja, serta bakso daging sapi yang diganti dengan daging celeng (Hariyadi, 2015a). Selain itu, adanya penggunaan yang salah (misuse) sejumlah bahan kimia berbahaya pada pangan seperti boraks, formalin, rhodamin B, dan kuning metanil (Dewanti-Hariyadi dan Hariyadi, 2012).

World Health Organization (WHO) mengeluarkan resolusi pada tahun 2002 mengenai adanya ancaman nyata penyebaran agen kontaminan fisik, kimia, atau radioaktif melalui makanan yang ditujukan untuk membahayakan masyarakat (WHO, 2002). Contoh kejadian terkait food defense adalah kontaminasi menggunakan kultur Salmonella typhimurium pada restoran salad bar yang mengakibatkan 751 orang terkena salmonellosis

*Penulis Korespodensi 
pada tahun 1984 di Amerika Serikat (Torok et al., 1997).

Salah satu produk pangan yang pernah mengalami kejadian kontaminasi disengaja adalah susu segar. Jenis kontaminasi yang dilakukan umumnya terkait pemalsuan, antara lain penambahan air, santan, air kelapa, air cucian beras, dan air tajin (Saleh, 2004) serta penambahan melamin pada susu sapi di Tiongkok pada tahun 2008 (Gossner et al., 2009).

Penanganan risiko kontaminasi pada pangan di Indonesia umumnya dilakukan berkaitan dengan risiko food safety akibat tindakan yang tidak disengaja. Metode penanganan risiko yang umum diterapkan oleh industri pangan antara lain Hazard Analysis and Critical Control Points (HACCP) atau ISO 22000:2005 Food safety management systems. Metode penanganan risiko tersebut tidak dapat menangani risiko terkait food fraud dan food defense. Untuk itu diperlukan adanya model manajemen risiko terkait kontaminasi disengaja sehingga tingkat keamanan produk pangan dapat meningkat. Tujuan penelitian ini adalah menyusun model manajemen risiko kontaminasi disengaja pada rantai pasok susu pasteurisasi.

Tabel 1. Daftar responden

\section{METODE PENELITIAN}

Penelitian ini dilakukan melalui pendekatan studi kasus di PT. XYZ, salah satu Industri Pengolahan Susu (IPS) yang berlokasi di Jakarta pada bulan Mei sampai dengan Juli 2017. Metode yang digunakan adalah Threat Assesment Critical Control Point (TACCP) yang bersumber dari PAS 96:2014 Guide to protecting and defending food and drink from deliberate attack (BSI, 2014).

\section{Pengumpulan Data dan Responden}

Data primer diperoleh melalui observasi lapangan, wawancara dengan responden, dan Focus Group Discussion (FGD). Data sekunder diperoleh dari pustaka dan publikasi ilmiah. Penentuan responden menggunakan metode purposive sampling, yaitu memilih pakar yang kompeten dari PT. XYZ yang memahami aliran produk susu pasteurisasi. Responden yang terlibat dapat dilihat pada Tabel 1.

\section{Tahapan Penelitian}

Gambar 1.

\begin{tabular}{clll}
\hline No & \multicolumn{1}{c}{ Institusi } & \multicolumn{1}{c}{ Jabatan } & \multicolumn{1}{c}{ Metode } \\
\hline 1. & Koperasi Pengumpul Susu & $\begin{array}{l}\text { 2 orang Peternak dan 1 orang } \\
\text { Supervisor Milk Treatment }\end{array}$ & Observasi lapang, Wawancara \\
2. & $\begin{array}{l}\text { Dept. Fresh Milk } \\
\text { Development Services }\end{array}$ & 1 orang Coordinator & Wawancara \\
3. & Dept. Produksi & 2 orang Supervisor & Observasi lapang, Wawancara, FGD \\
4. & Dept. Quality \& Food Safety & 1 orang Manajer dan 1 & Wawancara, FGD \\
5. & Dept. Warehouse & 1 orang Supervisor & Observasi lapang, Wawancara, FGD \\
6. & Dept. Quality Assurance & 1 orang Supervisor & FGD \\
7. & PT. XYZ Distribution & 1 orang Manajer & Wawancara \\
8. & Div. Cold Chain & 1 orang Manajer & Wawancara \\
\hline
\end{tabular}

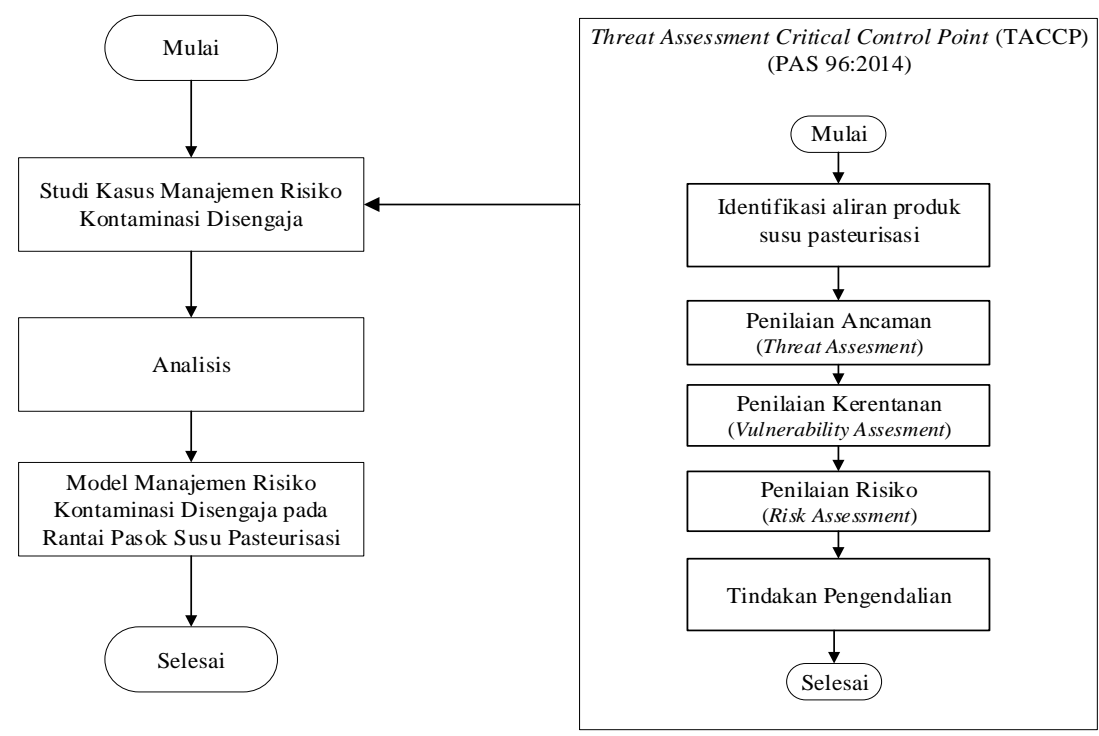

Gambar 1. Tahapan Penelitian 


\section{Studi Kasus Manajemen Risiko Kontaminasi} Disengaja

Identifikasi Aliran Produk Susu Pasteurisasi

Identifikasi dilakukan melalui observasi lapang ke salah satu koperasi pengumpul susu dan PT. XYZ. Wawancara dilakukan dengan responden untuk mendapatkan data aktor dan aliran rantai pasok yang dilalui produk susu pasteurisasi.

\section{Penilaian Ancaman (Threat Assesment)}

Penilaian ancaman dilakukan untuk mendapatkan tipe pelaku dan ancaman terkait kontaminasi disengaja melalui studi literatur, wawancara, dan FGD. Responden yang terlibat.

\section{Penilaian Kerentanan (Vulnerability Assesment)} Identifikasi dilakukan pada tiap tahapan produksi susu pasteurisasi untuk menilai adanya kelemahan yang dapat meningkatkan peluang terjadinya ancaman kontaminasi disengaja. Penilaian disertai dengan identifikasi personel yang memiliki akses, tindakan preventif atau mitigasi yang diterapkan, jenis adulterant atau kontaminan yang digunakan, dan kemungkinan terdeteksi oleh metode QA/QC yang diterapkan.

\section{Penilaian Risiko (Risk Assesment)}

Penilaian risiko dilakukan melalui FGD dengan memberikan skor peluang (likelihood) (Tabel 2) dan dampak (impact) (Tabel 3) pada tiap ancaman yang teridentifikasi. Kategori risiko dan tipe ancaman didapat sesuai matriks risiko pada Tabel 4 .

\section{Penentuan Tindakan Pengendalian}

FGD dilakukan untuk menentukan tindakan pengendalian bagi masing-masing ancaman. Tindakan pengendalian dapat dipilih terdiri dari tindakan yang sudah diterapkan atau tindakan pengendalian tambahan bila belum diterapkan.

Tabel 2. Kategori peluang (likelihood)

\begin{tabular}{|c|c|c|c|c|}
\hline Bobot & Kategori & $\begin{array}{l}\text { Kemungkinan } \\
\text { kejadian }\end{array}$ & Frekuensi & Metode Pengamanan \\
\hline 5 & $\begin{array}{l}\text { Very High } \\
\text { Chance }\end{array}$ & $\begin{array}{l}\text { Sangat besar } \\
\text { kemungkinan terjadi }\end{array}$ & $\begin{array}{l}\geq 5 \text { kejadian dalam periode } \\
5 \text { tahun }\end{array}$ & $\begin{array}{l}\text { Tidak ada metode } \\
\text { pengamanan }\end{array}$ \\
\hline 4 & High Chance & $\begin{array}{l}\text { Besar kemungkinan } \\
\text { terjadi }\end{array}$ & $\begin{array}{l}4 \text { kejadian dalam periode } 5 \\
\text { tahun }\end{array}$ & $\begin{array}{l}1 \text { metode pengamanan } \\
\text { tersedia }\end{array}$ \\
\hline 3 & Some Chance & $\begin{array}{l}\text { Cukup besar } \\
\text { kemungkinan terjadi }\end{array}$ & $\begin{array}{l}3 \text { kejadian dalam periode } 5 \\
\text { tahun }\end{array}$ & $\begin{array}{l}2 \text { metode pengamanan } \\
\text { tersedia }\end{array}$ \\
\hline 2 & May Happen & $\begin{array}{l}\text { Kecil kemungkinan } \\
\text { terjadi }\end{array}$ & $\begin{array}{l}2 \text { kejadian dalam periode } 5 \\
\text { tahun }\end{array}$ & $\begin{array}{c}3 \text { metode pengamanan } \\
\text { tersedia }\end{array}$ \\
\hline 1 & $\begin{array}{l}\text { Unlikely to } \\
\text { happen }\end{array}$ & $\begin{array}{l}\text { Sangat kecil } \\
\text { kemungkinan terjadi }\end{array}$ & $\begin{array}{l}\text { tidak pernah atau } 1 \\
\text { kejadian dalam periode } 5 \\
\text { tahun }\end{array}$ & $\begin{array}{c}4 \text { metode pengamanan } \\
\text { tersedia }\end{array}$ \\
\hline
\end{tabular}

Sumber : adaptasi BSI (2014)

Tabel 3. Kategori dampak (impact)

\begin{tabular}{|c|c|c|c|c|}
\hline Bobot & Kategori & Orang & Operasional & Reputasi \\
\hline 5 & Catastrophic & $\geq 2$ orang meninggal & Tidak berproduksi & $\begin{array}{l}\text { Menjadi perhatian internasional, } \\
\text { pemanggilan oleh pemerintah } \\
\text { Dimuat dalam media } \\
\text { nasional/internasional } \\
\text { Dampak jangka panjang terhadap } \\
\text { "brand". }\end{array}$ \\
\hline 4 & Major & $\begin{array}{l}1 \text { orang meninggal } \\
\text { atau } \geq 3 \text { orang sakit } \\
\text { ringan atau } \geq 2 \text { sakit } \\
\text { parah }\end{array}$ & $\begin{array}{l}\text { Gangguan pada line } \\
\text { produksi menyebabkan } \\
\text { produk di reject }\end{array}$ & $\begin{array}{l}\text { Menjadi perhatian publik, politik, } \\
\text { dan media secara nasional. } \\
\text { Operasional dibatasi. }\end{array}$ \\
\hline 3 & Significant & $\begin{array}{l}1 \text { orang sakit parah } \\
\text { atau perawatan di } R S \\
\text { atau } \geq 2 \text { sakit ringan }\end{array}$ & $\begin{array}{l}\text { Gangguan pada line } \\
\text { produksi menyebabkan } \\
\text { produk di hold }\end{array}$ & $\begin{array}{l}\text { Menjadi perhatian secara nasional, } \\
\text { Pemeriksaan oleh lembaga } \\
\text { eksternal. . }\end{array}$ \\
\hline 2 & Some & $\begin{array}{l}\text { Sakit yang } \\
\text { memerlukan } \\
\text { penanganan medis dan } \\
\text { atau istirahat bekerja }\end{array}$ & $\begin{array}{l}\text { Gangguan pada line } \\
\text { produksi menyebabkan } \\
\text { produk di reproses }\end{array}$ & $\begin{array}{l}\text { Investigasi oleh manajemen } \\
\text { puncak. } \\
\text { Menjadi perhatian media lokal. }\end{array}$ \\
\hline 1 & Minor & Sakit ringan atau $\mathrm{P} 3 \mathrm{~K}$ & $\begin{array}{l}\text { Gangguan pada line } \\
\text { produksi namun tidak } \\
\text { berpengaruh pada } \\
\text { produk }\end{array}$ & $\begin{array}{l}\text { Pemeriksaan oleh manajemen } \\
\text { puncak. } \\
\text { Menjadi pembicaraan tingkat lokal. }\end{array}$ \\
\hline
\end{tabular}


Tabel 4. Matriks Risiko

\begin{tabular}{|c|c|c|c|c|c|c|}
\hline Catastrophic & 5 & & & & & $\begin{array}{l}\text { Very high risk/ } \\
\text { Threat A }\end{array}$ \\
\hline Major & 4 & & & & $\begin{array}{l}\text { High risk/ } \\
\text { Threat } B\end{array}$ & \\
\hline Significant & 3 & & & $\begin{array}{l}\text { Moderate risk / } \\
\text { Threat C }\end{array}$ & & \\
\hline Some & 2 & & $\begin{array}{l}\text { Low risk / } \\
\text { Threat D }\end{array}$ & & & \\
\hline Minor & 1 & $\begin{array}{l}\text { Negligible risk } \\
\text { / Threat E }\end{array}$ & & & & \\
\hline & & 1 & 2 & 3 & 4 & 5 \\
\hline & & $\begin{array}{l}\text { Unlikely to } \\
\text { happen }\end{array}$ & May Happen & Some Chance & High Chance & $\begin{array}{l}\text { Very High } \\
\text { Chance }\end{array}$ \\
\hline
\end{tabular}

Sumber : adaptasi BSI (2014)

\section{Analisis}

Analisis deskriptif dilakukan untuk menganalisis faktor-faktor yang berpengaruh dalam usaha pencegahan ancaman kontaminasi disengaja yang dikelompokkan menjadi tindakan preventif (prevention), deteksi (detection), menghalangi (deterrence), serta pengaruh struktur dan manajemen rantai pasok.

\section{Model Manajemen Risiko Kontaminasi Disengaja Rantai Pasok Susu Pasteurisasi}

Model manajemen risiko kontaminasi disengaja disusun secara deskriptif yang meliputi tipe ancaman, tingkat risiko, dan faktor-faktor terkait pencegahan yang dapat diterapkan.

\section{HASIL DAN PEMBAHASAN}

\section{Identifikasi Rantai pasok Susu Pasteurisasi PT. XYZ}

Rantai pasok susu pasteurisasi dan proses produksi di PT. XYZ dapat dilihat pada Gambar 2. Anggota rantai pasok terdiri dari pemasok, manufaktur, distributor, dan pelanggan. Pemasok susu segar terdiri dari dua jenis, yaitu koperasi pengumpul susu (KUD dan Koperasi Pertanian) dan perusahaan peternakan. Produk susu pasteurisasi akan didistribusikan oleh distributor yang berasal dari satu grup induk. Pelanggan terdiri dari supermarket, food service, depo, dan institusi.

\section{Penilaian Ancaman}

Ancaman kontaminasi disengaja pada pemasok terdiri dari economically motivated adulteration (EMA), yaitu berupa pemalsuan susu dan pencurian susu yang disertai penambahan air sebagaimana pada Tabel 5.

Ancaman terkait risiko food defense adalah kontaminasi disengaja yang dapat membahayakan kesehatan konsumen produk. Kontaminasi disengaja berpotensi terjadi pada tahap IPS, distributor, atau pelanggan. Penilaian ancaman pada IPS, distributor, dan pelanggan dapat dilihat pada Tabel 6 .

\section{Penilaian Kerentanan}

Penilaian kerentanan dilakukan untuk mengidentifikasi tahapan yang memiliki kelemahan dan meningkatkan peluang terjadinya kontaminasi disengaja. Hasil penilaian yang dilakukan terhadap kerentanan pada tahapan produksi susu pasteurisasi di PT. XYZ didapatkan adanya kerentanan pada tahap pengambilan sampel, penyimpanan susu segar, termisasi, penyimpanan thermized fresh milk, dumping, mixing dan heating, dan penyimpanan susu work in process. Kerentanan yang teridentifikasi adalah adanya manhole tangki yang mudah diakses, supervisi minimum karena operator bekerja sendirian, dan material terpapar karena adanya proses pembukaan kemasan raw material. Tahapan tersebut dapat diakses oleh operator produksi dan inspektor QC. Tindakan yang sudah diterapkan antara lain melalui pemantauan dengan kamera CCTV, pengerjaan oleh 1 tim operator, dan pengawasan oleh leader.

\section{Penilaian Risiko dan Tindakan Pengendalian}

Hasil penilaian risiko dan tindakan pengendalian dapat dilihat pada Tabel 7. Perbedaan risiko pada tiap tahapan dikarenakan adanya perbedaan penilaian tingkat kemungkinan kejadian dengan memperhatikan pertimbangan pada hasil penilaian ancaman dan tindakan mitigasi yang sudah dilakukan. Tindakan pengendalian tambahan diusulkan untuk diterapkan pada tahapan produksi yang memiliki akses manhole pada alat produksi berbentuk tangki berupa penguncian. Pemasangan kamera CCTV diusulkan untuk ditambahkan pada area produksi yang belum terpasang. Peningkatan supervisi diterapkan untuk area kerja karyawan yang bekerja sendirian.

\section{Hasil Analisis}

Usaha-usaha penanganan ancaman kontaminasi yang disengaja telah dilakukan oleh PT. $\mathrm{XYZ}$ untuk menurunkan risiko terjadinya kejadian tersebut. Tindakan penanganan ancaman kontaminasi yang disengaja dapat dikelompokkan menjadi tindakan preventif (prevention), deteksi (detection), dan menghalangi (deterrence) (Hariyadi, 2015b; Spink et al., 2016). 
Tabel 5. Penilaian ancaman pada pemasok

\begin{tabular}{|c|c|c|c|}
\hline No & Tipe Ancaman & $\begin{array}{c}\text { Pelaku } \\
\text { potensial }\end{array}$ & Justifikasi \\
\hline 1 & $\begin{array}{l}\text { Economically } \\
\text { Motivated } \\
\text { Adulteration (EMA) / } \\
\text { pemalsuan susu } \\
\text { berupa penambahan : } \\
\text { air, lemak nabati, } \\
\text { pati/tepung, glukosa, } \\
\text { sukrosa, antibiotik, } \\
\text { karbonat, boraks, } \\
\text { peroksida, formalin, } \\
\text { urea, melamin atau zat } \\
\text { turunannya }\end{array}$ & $\begin{array}{l}\text { Koperasi } \\
\text { pengumpul } \\
\text { susu }\end{array}$ & $\begin{array}{l}\text { - Data historis perusahaan pernah terjadi } \\
\text { - Motif : menjaga agar kondisi susu tetap dapat diterima dan } \\
\text { menjaga nilai uang dari susu tersebut. } \\
\text { Kemampuan : } \\
\text { - Peternak hanya mampu menggunakan adulterant sederhana } \\
\text { dan mudah didapat } \\
\text { - Penggunaan adulterant yang lebih kompleks diduga dapat } \\
\text { dilakukan oleh koperasi atau perusahaan peternakan, } \\
\text { meskipun belum pernah ditemukan secara langsung } \\
\text { - Trend tindakan pemalsuan susu menurun } \\
\text { Potensi pemalsuan susu menurun dengan penerapan uji } \\
\text { pemalsuan di koperasi dan IPS }\end{array}$ \\
\hline 2 & $\begin{array}{l}\text { Pencurian susu } \\
\text { disertai penambahan } \\
\text { air }\end{array}$ & Supir truk & $\begin{array}{l}\text { - Data historis perusahaan pernah terjadi } \\
\text { - Motif mencuri susu segar saat transportasi ke IPS. } \\
\text { Penambahan air dilakukan untuk menutupi volume susu yang } \\
\text { hilang } \\
\text { - Kemampuan : Pencurian dilakukan saat berhenti pada } \\
\text { perjalanan dari koperasi ke IPS } \\
\text { - Potensi pencurian susu menurun dengan penggunaan segel } \\
\text { khusus pada valve pipa truk susu }\end{array}$ \\
\hline
\end{tabular}

Tabel 6. Penilaian ancaman pada IPS, distributor, dan pelanggan

\begin{tabular}{|c|c|c|c|}
\hline No & $\begin{array}{c}\text { Tipe } \\
\text { Ancaman }\end{array}$ & Pelaku potensial & Justifikasi \\
\hline 1 & $\begin{array}{l}\text { Kontaminasi } \\
\text { disengaja }\end{array}$ & $\begin{array}{l}\text { Karyawan IPS } \\
\text { Karyawan } \\
\text { gudang } \\
\text { distributor } \\
\text { Supir Truk } \\
\text { Karyawan di } \\
\text { pelanggan }\end{array}$ & $\begin{array}{l}\text { - Data historis perusahaan belum pernah terjadi } \\
\text { - Keluhan pelanggan terkait kualitas atau akibat kesalahan } \\
\text { penanganan } \\
\text { - Motif : merusak brand image produk PT. XYZ dan merugikan } \\
\text { perusahaan. } \\
\text { Kemampuan : } \\
\text { - menangani produk secara langsung } \\
\text { - operator pada IPS memiliki pengetahuan dan akses pada } \\
\text { proses pembuatan produk, serta akses terhadap bahan } \\
\text { kontaminan di area pabrik. } \\
\text { - Potensi saat produk sudah dikemas rendah : sifat produk susu } \\
\text { pasteurisasi mudah rusak bila ada kebocoran kemasan / segel } \\
\text { dan penggunaan GPS dan data logger saat distribusi. }\end{array}$ \\
\hline 2 & $\begin{array}{l}\text { Kontaminasi } \\
\text { disengaja }\end{array}$ & $\begin{array}{l}\text { Teroris } \\
\text { Kriminal } \\
\text { Kompetitor } \\
\text { Pihak ketiga } \\
\text { Tamu }\end{array}$ & $\begin{array}{l}\text { - Data historis perusahaan belum pernah terjadi } \\
\text { - Tidak ada historis ancaman dari teroris pada industri pangan } \\
\text { di Indonesia } \\
\text { - Keluhan pelanggan terkait kualitas atau akibat kesalahan } \\
\text { penanganan } \\
\text { - Motif : membahayakan kesehatan masyarakat secara luas atau } \\
\text { menciptakan teror } \\
\text { - Kemampuan : membutuhkan pengetahuan mengenai area atau } \\
\text { fasilitas pada pabrik, gudang distributor, dan gudang pada } \\
\text { pelanggan } \\
\text { - Potensi rendah adanya adanya fasilitas dan prosedur } \\
\text { pengamanan }\end{array}$ \\
\hline
\end{tabular}


Tabel 7. Kategori risiko dan tindakan pengendalian

\begin{tabular}{|c|c|c|c|c|c|c|c|c|}
\hline No & $\begin{array}{c}\text { Pelaku } \\
\text { Potensial }\end{array}$ & Ancaman & Tahapan / Lokasi & $\mathbf{L}$ & $\mathbf{I}$ & $\begin{array}{l}\text { Kategori } \\
\text { Risiko }\end{array}$ & $\begin{array}{c}\text { Tipe } \\
\text { Ancaman }\end{array}$ & $\begin{array}{c}\text { Tindakan } \\
\text { Pengendalian }\end{array}$ \\
\hline \multicolumn{9}{|c|}{ Pemasok } \\
\hline 1 & Peternak & $\begin{array}{l}\text { EMA - } \\
\text { penambahan } \\
\text { adulterant }\end{array}$ & Kandang & 1 & 4 & Low & Threat D & Uji pemalsuan \\
\hline 2 & $\begin{array}{l}\text { Koperasi / } \\
\text { Perusahaan } \\
\text { Peternakan }\end{array}$ & $\begin{array}{l}\text { EMA - } \\
\text { penambahan } \\
\text { adulterant }\end{array}$ & Cooling Center & 1 & 4 & Low & Threat D & Uji pemalsuan \\
\hline 3 & Sopir Truk & $\begin{array}{l}\text { Pencurian } \\
\text { susu dengan } \\
\text { penambahan } \\
\text { air }\end{array}$ & $\begin{array}{l}\text { Transportasi Susu ke } \\
\text { IPS }\end{array}$ & 1 & 2 & Negligible & Threat $\mathrm{E}$ & Segel \\
\hline \multicolumn{9}{|c|}{ Industri Pengolahan Susu } \\
\hline \multirow[t]{7}{*}{1} & Internal : & Kontaminasi & Pengambilan sampel & 2 & 4 & Moderate & Threat $\mathrm{C}$ & Pemantauan CCTV \\
\hline & Karyawan & disengaja & $\begin{array}{l}\text { Penyimpanan Susu } \\
\text { Segar (SV) }\end{array}$ & 2 & 4 & Moderate & Threat $\mathrm{C}$ & $\begin{array}{l}\text { Penguncian Manhole } \\
\text { tangki }\end{array}$ \\
\hline & & & Termisasi & 2 & 4 & Moderate & Threat $\mathrm{C}$ & $\begin{array}{l}\text { Peningkatan } \\
\text { supervisi, pemantauan } \\
\text { CCTV }\end{array}$ \\
\hline & & & $\begin{array}{l}\text { Penyimpanan } \\
\text { thermized fresh milk } \\
\text { (SV) }\end{array}$ & 2 & 4 & Moderate & Threat $\mathrm{C}$ & $\begin{array}{l}\text { Penguncian Manhole } \\
\text { tangki }\end{array}$ \\
\hline & & & Dumping & 2 & 4 & Moderate & Threat $\mathrm{C}$ & Pemantauan CCTV \\
\hline & & & Mixing dan Heating & 1 & 4 & Low & Threat D & $\begin{array}{l}\text { Penguncian Manhole } \\
\text { tangki }\end{array}$ \\
\hline & & & $\begin{array}{l}\text { Penyimpanan susu } \\
\text { WIP (SV) }\end{array}$ & 1 & 4 & Low & Threat D & $\begin{array}{l}\text { Penguncian Manhole } \\
\text { tangki }\end{array}$ \\
\hline 2 & $\begin{array}{l}\text { Eksternal : } \\
\text { Teroris, } \\
\text { Kriminal, } \\
\text { Kompetitor, } \\
\text { Pihak ketiga, } \\
\text { visitor }\end{array}$ & $\begin{array}{l}\text { Kontaminasi } \\
\text { disengaja }\end{array}$ & IPS & 1 & 4 & Low & Threat D & $\begin{array}{l}\text { Fasilitas, prosedur } \\
\text { pengamanan, dan } \\
\text { pendampingan visitor }\end{array}$ \\
\hline \multicolumn{9}{|c|}{ Distributor } \\
\hline 1 & $\begin{array}{l}\text { Internal : } \\
\text { Karyawan, } \\
\text { Gudang, Sopir } \\
\text { Truk Delivery }\end{array}$ & $\begin{array}{l}\text { Kontaminasi } \\
\text { disengaja }\end{array}$ & Truk/Gudang & 1 & 4 & Low & Threat D & $\begin{array}{l}\text { GPS, data logger, dan } \\
\text { penguncian pada truk }\end{array}$ \\
\hline 2 & $\begin{array}{l}\text { Eksternal: } \\
\text { Teroris, } \\
\text { Kriminal, } \\
\text { Kompetitor, } \\
\text { Sopir Truk } \\
\text { Ekspedisi }\end{array}$ & $\begin{array}{l}\text { Kontaminasi } \\
\text { disengaja }\end{array}$ & Truk/Gudang & 1 & 4 & Low & Threat D & $\begin{array}{l}\text { Fasilitas, prosedur } \\
\text { pengamanan, dan } \\
\text { pendampingan visitor, } \\
\text { GPS, data logger, dan } \\
\text { penguncian pada truk }\end{array}$ \\
\hline \multicolumn{9}{|c|}{ Pelanggan } \\
\hline 1 & $\begin{array}{l}\text { Internal : } \\
\text { Karyawan di } \\
\text { Pelanggan }\end{array}$ & $\begin{array}{l}\text { Kontaminasi } \\
\text { disengaja }\end{array}$ & Supermarket & 1 & 4 & Low & Threat D & $\begin{array}{l}\text { Pemeriksaan oleh } \\
\text { SPG, pembatasan } \\
\text { akses gudang bagi } \\
\text { orang luar }\end{array}$ \\
\hline 2 & Eksternal: & & Depo & 1 & 4 & Low & Threat D & Pemeriksaan chiller \\
\hline 3 & Teroris, & & Food Service & 1 & 4 & Low & Threat D & periodik, pembatasan \\
\hline 4 & $\begin{array}{l}\text { Kriminal, } \\
\text { Kompetitor }\end{array}$ & & Institusi & 1 & 4 & Low & Threat D & $\begin{array}{l}\text { akses gudang bagi } \\
\text { orang luar }\end{array}$ \\
\hline
\end{tabular}

Tindakan preventif adalah penerapan tindakan pencegahan untuk menurunkan peluang terjadinya pemalsuan. Tindakan mendeteksi adalah menemukan adulterant spesifik atau anomali produk. Tindakan menghalangi adalah tindakan pencegahan untuk menghentikan pelaku (Spink et al., 2016).

Tindakan preventif yang telah dilakukan oleh PT. XYZ antara lain pembinaan kepada pemasok yang dilakukan oleh departemen khusus pada perusahaan, pembinaan oleh koperasi 
pengumpul susu kepada peternak melalui tenaga penyuluh atau training, sertifikasi FSSC 22000 Food Safety System Certification dan penggunaan Threat Assessment Critical Control Point (TACCP), peningkatan awareness melalui training dan penyusunan TACCP oleh masing-masing Departemen, penerapan standar ISO 9001:2008, ISO 22000:2005, dan ISO 17025:2005, pelaksanaan mock recall untuk penarikan produk, dan pemeriksaan kondisi product display harian.

Van Ruth et al. (2017) menyatakan bahwa sistem monitoring untuk pengendalian incoming material termasuk rencana sampling sistematis, metode deteksi pemalsuan yang spesifik dan akurat, dokumentasi dan monitoring pemalsuan yang jelas akan meningkatkan kemungkinan dalam mendeteksi produk yang dipalsukan. Ketersediaan atau ketiadaan metode deteksi mempengaruhi kerentanan terhadap pemalsuan. Tindakan deteksi antara lain pemeriksaan awal di TPK (milk can, visual, berat jenis, suhu, dan uji alkohol), pengujian di koperasi (uji pemalsuan (karbonat), uji antibiotik, uji kualitas, dan uji mikroba), uji pemalsuan susu di IPS (lemak nabati, pati/tepung, glukosa, sukrosa, karbonat, boraks, peroksida, formalin, urea, melamin, dan antibiotik), dan pengujian pada IPS pada tahap penerimaan raw material, work in process dan finish goods.

Tindakan menghalangi antara lain segel khusus pada pipa dan tutup tangki truk dari pemasok, penggunaan CCTV dan pembatasan akses pada peralatan produksi, penggunaan gembok pada angkutan distribusi dilakukan disertai pemeriksaan saat keberangkatan dan kedatangan truk, pelaksanaan prosedur penerimaan tamu dan pengamanan, penerapan segregasi area dengan prosedur penggunaan seragam tertentu, izin memasuki area dan pendampingan, penerapan teknologi GPS dan data logger, dan kemasan produk dengan seal pada tutup kemasan atau sistem sobek.

Faktor lain yang berpengaruh adalah struktur dan manajemen rantai pasok susu pasteurisasi. Chen et al. (2014) menyatakan bahwa kasus melamin pada susu formula di Tiongkok secara umum disebabkan karena Sanlu Grup selaku industri pengolahan susu kurang melakukan supervisi dan pengendalian pada rantai pasoknya seperti kurangnya pelatihan dan monitoring pemasok, peternak dan pengumpul susu yang bekerjasama tidak mendapat pelatihan pengetahuan dasar pengendalian mutu dan pemeriksaan latar belakang, dan pengumpul susu terorganisasi secara baik serta kurangnya dokumentasi. Dalam mengelola struktur dan manajemen rantai pasok, tindakan yang telah dilakukan antara lain adalah PT. XYZ selaku IPS melakukan kerjasama dengan pemasok yang berbadan hukum. PT. XYZ tidak melakukan kerjasama dengan peternak langsung atau pedagang pengumpul, IPS dan distributor yang berasal dari grup yang sama, Pemasok memiliki organisasi dan sumberdaya untuk memastikan susu yang dipasok sesuai persyaratan, pemasok terikat kontrak memasok susu sesuai persyaratan yang ditetapkan oleh IPS dan adanya mekanisme penentuan harga, PT. XYZ memberikan bantuan dana dan peralatan serta melakukan pembinaan, koperasi memperhatikan jarak yang harus ditempuh ke IPS, dan persyaratan yang ditetapkan pada pelanggan terkait penanganan dan penyimpanan produk

\section{Model Manajemen Risiko Kontaminasi Disengaja Rantai Pasok Susu Pasteurisasi}

Model manajemen risiko kontaminasi yang disengaja dilakukan melalui penilaian ancaman dan pelaku yang dapat melakukan tindakan kontaminasi, penilaian kerentanan pada aliran produk susu pasteurisasi, penilaian risiko, dan penentuan tindakan pengendalian. Model manajemen risiko kontaminasi disengaja dapat dilihat pada Gambar 3.

Tindakan preventif yang dapat dilakukan antara lain pembinaan ke peternak oleh koperasi susu, pembinaan ke pemasok oleh IPS, penerapan standar terkait food fraud dan food defense, peningkatan awareness terkait food fraud dan food defense, penerapan standar terkait kualitas dan keamanan pangan, peningkatan kemampuan ketertelusuran dan penarikan produk, pemeriksaan oleh SPG, dan pemeriksaan chiller secara periodik. Audit yang dilakukan oleh pihak ketiga dalam memastikan penerapan standar terkait food fraud dan food defense atau standar manajemen mutu dapat digunakan untuk memastikan komitmen manajemen dan penanganan produk susu yang tidak memenuhi standar agar tidak dicampur dengan produksi produk berikutnya pada koperasi susu atau IPS.

Tindakan deteksi yang dapat dilakukan antara lain uji pemalsuan susu dan uji kualitas susu segar di koperasi susu, serta uji pemalsuan susu saat penerimaan, uji kualitas produk, dan pemutakhiran jenis adulterant dan metode uji di IPS. Tindakan menghalangi yang dapat dilakukan antara lain diterapkannya prosedur dan fasilitas keamanan, penerapan teknologi (contoh : CCTV), penguncian dan pembatasan area, penggunaan kemasan produk yang aman, penggunaan GPS dan data logger, dan penggunaan segel atau penguncian pada truk.

Struktur dan manejemen rantai pasok yang dapat diterapkan antara lain penerapan syarat penerimaan susu, mekanisme penentuan harga susu, pemilihan pemasok yang berkomitmen terhadap kualitas dan keamanan produk, pemilihan distributor dan pelanggan yang berkomitmen terhadap kualitas dan keamanan produk, dan mendorong penerapan tindakan pencegahan terhadap kontaminasi disengaja terkait risiko food defense pada distributor dan pelanggan.

Ancaman kontaminasi yang disengaja secara umum terdiri dari risiko food fraud dan risiko food defense. Penanganan ancaman kontaminasi yang disengaja dapat diterapkan bersamaan dengan 
penanganan ancaman kontaminasi tidak disengaja sehingga meningkatkan perlindungan produk susu. Penerapan tindakan pengendalian tambahan akan menurunkan peluang terjadinya. Penilaian risiko kontaminasi yang disengaja pada susu pasteurisasi pada studi kasus PT. XYZ tergolong aman dengan kategori low risk.

\section{KESIMPULAN DAN SARAN}

\section{Kesimpulan}

Ancaman terkait risiko food fraud berpotensi dilakukan oleh pemasok susu, baik peternak, koperasi pengumpul susu, atau perusahaan peternakan. Peternak memiliki pengetahuan terbatas dalam penggunaan adulterant. Koperasi pengumpul susu atau perusahaan peternakan diduga memiliki kemampuan menggunakan adulterant yang lebih kompleks. Ancaman terkait risiko food defense memiliki potensi lebih besar dilakukan oleh karyawan dari pihak internal saat proses produksi susu pasteurisasi di IPS. Kerentanan pada tahapan produksi susu pasteurisasi umumnya berkaitan dengan peralatan yang memiliki akses ke produk seperti tangki yang memiliki manhole atau akses. Pencegahan terhadap ancaman kontaminasi disengaja dapat dilakukan dengan menerapkan tindakan preventif, deteksi, dan menghalangi, serta penerapan manajemen rantai pasok dapat menurunkan peluang dan risiko terjadinya ancaman. Penerapan tindakan pencegahan dapat menurunkan risiko kontaminasi disengaja pada rantai pasok susu pasteurisasi dalam kategori low risk.

\section{Saran}

Model manajemen risiko terbatas pada hasil studi kasus di PT. XYZ. Limitasi penelitian yaitu penilaian kerentanan pada penelitian ini hanya dilakukan pada tahap IPS. Penelitian lanjutan diperlukan untuk memetakan tahapan pada masingmasing tahapan sehingga titik kerentanan dapat dipetakan secara lengkap sehingga penilaian risiko dapat dilakukan pada tiap titik kerentanan.

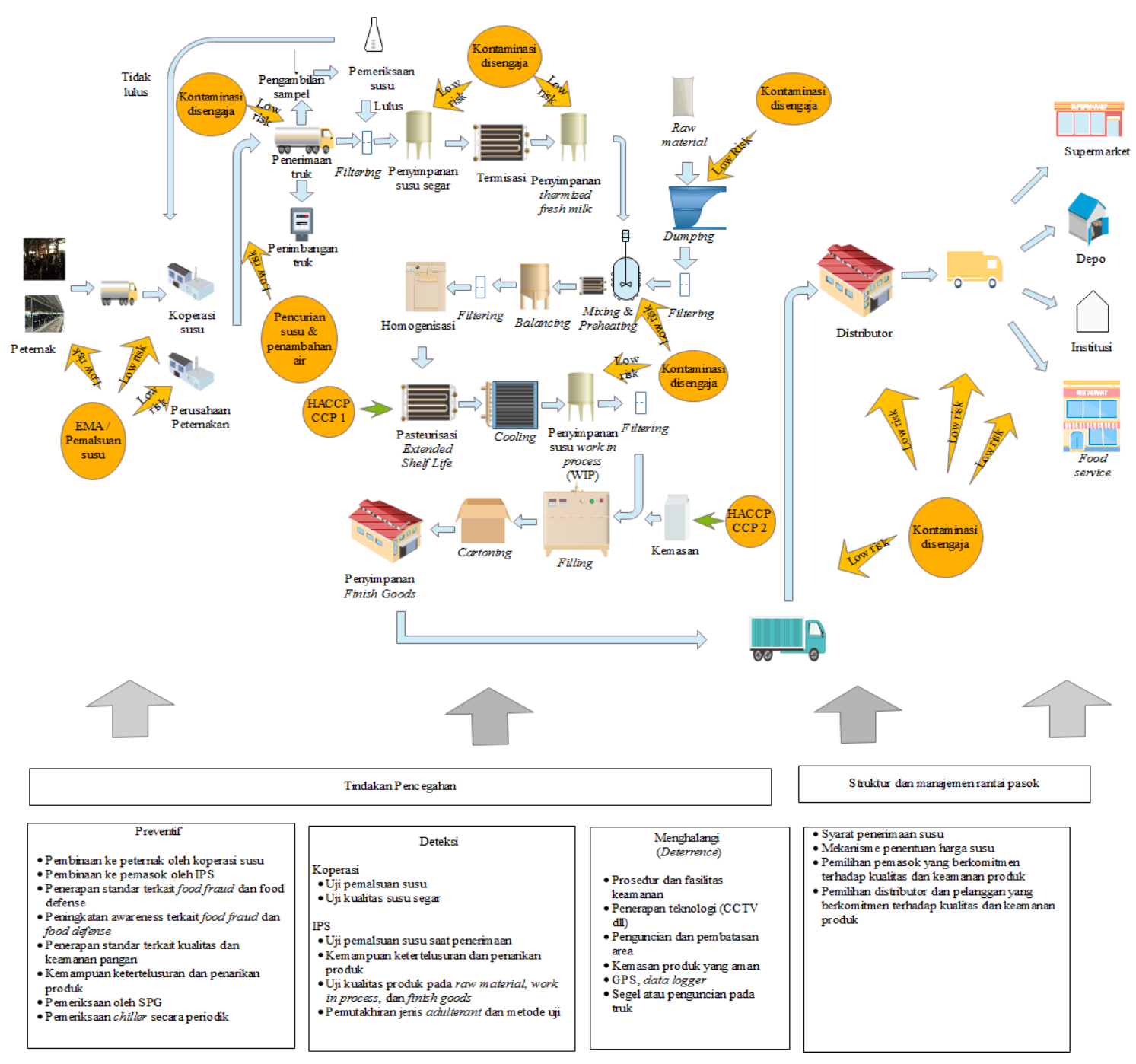

Gambar 3. Model manajemen risiko kontaminasi disengaja 


\section{UCAPAN TERIMA KASIH}

Penulis mengucapkan terima kasih kepada Lembaga Pengelola Dana Pendidikan (LPDP) atas dukungan dana yang diberikan pada penelitian ini.

\section{DAFTAR PUSTAKA}

[BPOM] Badan Pengawas Obat dan Makanan. 2016. Laporan Tahunan 2016. Jakarta (ID): BPOM.

[BSI] British Standards Institution. 2014. PAS 96:2014 Guide to protecting and defending food and drink from deliberate attack. London (UK) : BSI

Chen C, Zhang J, dan De laurentis T. 2014. Quality control in food supply chain management : An analytical model and case study of the adulterated milk incident in Chin. International Journal Production Economics. 152 : 188-199

Dewanti-Hariyadi R, dan Hariyadi P. 2012. Antisipasi terhadap isu-isu baru keamanan pangan. Pangan - Media Komunikasi dan Informasi 21(1) : $85-100$

Gossner CME, Schlundt J, Embarek PB, Hird S, Wong DLF, Beltran JJO, Teoh KN, Tritscher A. 2009. The melamine incident: implications for international food and feed safety. Environmental Health Perspectives 117 (12) : 1803 - 1808.

Hariyadi P. 2015a Mei 23. Ancaman Serius Pemalsuan Pangan. Kompas. Opini : 1-5
Hariyadi P. 2015b. Peranan Standar: Dari Keamanan Ke Pertahanan Pangan. SNI Valuasi 91(2):16-19.

Saleh E. 2004. Dasar Pengolahan Susu dan Hasil Ikutan Ternak. Sumatera Utara (ID): Universitas Sumatera Utara.

Spink J dan Moyer DC. 2011. Defining the public health threat of food fraud. Journal of Food Science 76 (9)

Spink J, Fortin ND, Moyer DC, Miao H, Wu Y. 2016. Food fraud prevention: policy, strategy, and decision-making implementation steps for a government agency or industry. Chimia $70: 320-328$.

Torok TJ, Tauxe RV, Wise RP, Livengood JR, Sokolow R, Mauvais S, Birkness KA, Skeels MR, Horan JM, Foster LR. 1997. A Large community outbreakof salmonellosis caused by intentional contamination of restaurant salad bars. Journal of the American Medical Association 278 (5) : 389-395.

van Ruth SM, Huisman W, dan Luning PA. 2017. Food fraud vulnerability and its key factors. Trends in Food Science \& Technology 67 : $70-75$.

[WHO] World Health Organization. 2002. Terrorist Threats to Food, Guidance for Establishing and Strengthening Prevention and Response Systems. Geneve (Switzerland) : WHO. 